\title{
Temporal changes of fine root overyielding and foraging strategies in planted monoculture and mixed forests
}

Weiwei Shu' ${ }^{1}$ Xiaoxiao Shen ${ }^{1}$, Pifeng Lei ${ }^{1,2^{*}}$, Wenhua Xiang ${ }^{1,2}$, Shuai Ouyang ${ }^{1,2}$ and Wende Yan ${ }^{1,2}$

\begin{abstract}
Background: Mixed forests are believed to enhance ecosystem functioning and sustainability due to complementary resource use, environmental benefits and improved soil properties. The facilitation between different species may induce overyielding. Meanwhile, the species-specific fine root foraging strategies and tradeoffs would determine the structure and dynamics of plant communities. Here the aim was to investigate the admixing effects of fine-root biomass, vertical distribution and morphology in Pinus massoniana-Cinnamomum camphora mixed plantations and corresponding monocultures at 10-, 24- and 45-year old stands.

Results: The fine root biomass in the Pinus-Cinnamomum mixed forest exerted a certain degree of overyielding effect. These positive admixing effects, however, did not enhance with forest stand development. The overall relative yield total ranged from 1.83 and 1.51 to 1.33 in 10-, 24- and 45-year-old stand, respectively. The overyielding was mainly attributed to the over-performance of late successional species, Cinnamomum, in mixed stands. The vertical fine root biomass distribution model showed fine roots of pioneer species, Pinus, shifted to the superficial layer when mixed with Cinnamomum. Furthermore, the specific root length (SRL) of Pinus was significantly higher in Pinus-Cinnamomum mixed stands than that in monocultures, and the magnitude of differences increased over time. However, the vertical fine-root distribution and SRL for Cinnamomum did not show significant differences between monoculture and mixtures.

Conclusions: Our results indicated that the magnitude of fine root overyielding in mixed forests showed a high degree of consistency with the total amount of fine root biomass itself, suggesting the overyielding effects in mixed forests were correlated with the degree of belowground interaction and competition degree involved. The late successional species, Cinnamomum, invested more carbon to belowground by increasing the fine root biomass in mixtures. While the pioneer species, Pinus, adapted to the presence of the species Cinnamomum by modification of vertical distribution and root morphological plasticity in the mixtures. These species-specific fine root foraging strategies might imply the differences of forest growth strategies of co-occurring species and contribute to the success and failure of particular species during the succession over time.
\end{abstract}

Keywords: Fine root biomass, Vertical distribution, Specific root length, Overyielding, Stand age

\section{Background}

In the global carbon cycle, roots of forest trees are an important reservoir of carbon, which is an important component of $\mathrm{C}$ pool in terrestrial ecosystem and plays a

\footnotetext{
*Correspondence: pifeng.lei@outlook.com

${ }^{1}$ Faculty of Life Science and Technology, Central South University

of Forestry and Technology, Changsha 410004, Hunan, China

Full list of author information is available at the end of the article
}

vital role on global carbon flux and carbon library $[1,2]$. In this context, in the past few decades, a lot of interests have been arose with fine root biomass and production in forest, since fine roots accounted for as much as onethird of global net primary productivity $[3,4]$ and are primary responsible for water and nutrient uptake by trees $[5,6]$. Belowground interactions among co-occurring species play critical roles on the community structure 
and distribution of plants. The plants are even capable of recognizing non-self neighbours and tend to proliferate more roots into substrate shared with coexisting species, and likely resulting in rooting aggregation and overyielding, which is defined as higher production or biomass in mixture than that in the corresponding monocultures [7]. Therefore, mixed forests are considered to enhance ecosystem functioning and sustainability due to complementary resource use, environmental benefits and to be less susceptible to abiotic hazards like wind throw and snow break than pure stands $[8,9]$.

Most studies investigating tree species diversity effects on aboveground and belowground productivity in forests, however, were based on comparisons between two species mixtures with monocultures. For example, a number of studies found a higher fine root biomass and production in mixtures [10-13], although other studies showed otherwise [14, 15]. Recently, more studies were carried out to disentangle the effects of species diversity on the fine root biomass and production in mixed forests containing four to five tree species and the results were still equivocal $[16,17]$. Notwithstanding, all these studies on the relationship between diversity and productivity were based on one particular growth stage, or one static stand age. To our knowledge, recently only one study has been conducted comparing the effects on tree species on fine root productivity at 8 and 34 years old [18]. Data on how fine root biomass, spatial distribution and morphology change at pure and mixed forests in relation to stand age, are comparatively few.

Fine root proliferation is greatly determined by environment conditions, such as nutrient supply in the soil, temperature and water. For example, Fine root vertical distribution is impacted by the spatial distribution of soil nutrients and moisture [19], as well as soil structure and bulk density [20]. Besides, with increasing forests development, the proportion of fine root biomass was prone to increase in the top soil [21] or indicate no change [2]. Furthermore, competition among individuals of the same species (intraspecific competition), as well as among different species populations (inter-specific competition), affects the process of tree root growth. Generally belowground competition depends on the soil exploitation capacity and exploitation efficiency of the fine-root systems of each plant, which were determined by the fine root biomass, surface area, root distribution within the soil horizons and specific root length (SRL) [22, 23]. Different plants within the community, in order to minimize competition for soil nutrients and moisture, may adjust the $C$ investment to fine roots and distribution, and/or morphological traits to adapt to the competition. Previous studies showed that beech developed a more dynamic and adaptive fine root foraging strategies, e.g. biomass and vertical distribution, comparing to competitive species in mixed stands [24, 25]. However, how the belowground interactions may shift with forest development is not clear, which may mirror the aboveground competition.

Here the temporal changes of fine root biomass, vertical distribution and fine root morphology were investigated in Pinus massoniana-Cinnamomum camphora mixed plantations and corresponding single species plantations at age of 10, 24 and 45 years. Our objectives were to determine the magnitude of admixing effects on fine root biomass over time and to assess the possible shifts of foraging strategies for pioneer species (P. massoniana) and late successional species (C. camphora) along forest development. In this study we specifically tested the hypotheses that: (i) the total standing fine root biomass are higher in the mixed stands than those in corresponding monocultures, and the magnitude of positive admixing effect increases with forest development; (ii) the fine root foraging strategies of co-existing species, including fine root biomass, vertical distribution and morphological traits, in mixed forests mirrors the growth strategies of different species with forest development.

\section{Methods}

\section{Field sites and experimental design}

This study was carried out in two different sites in Hunan province, China. One area is located in the Botanical Garden in Changsha $\left(28^{\circ} 06^{\prime} \mathrm{N}, 113^{\circ} 02^{\prime} \mathrm{E}\right)$. The annual rainfall on this site is $1422 \mathrm{~mm}$ and the mean annual temperature is $17.2^{\circ} \mathrm{C}$, belonging to typical subtropical monsoon climate. The altitude ranges from 50 to $100 \mathrm{~m}$. The soil type is Alliti-Udic Ferrosols with well-drained clayloam red soil developed from slate parent rock, and total $\mathrm{N}$ concentrations ranging from 0.57 to $1.56 \mathrm{~g} \mathrm{~kg}^{-1}$ in top $30 \mathrm{~cm}$ depth of the soil profile [26]. Single species and two species mixed patches, consisting of 24- and 45-year old $P$. massoniana were selected. In monocultures and mixed stand, few Pinus elliotii were also admixed here. Considering the similarity of growth characteristics and the difficulty of root separation between $P$. massoniana or $P$. elliotii, we treated them one group (thereafter called "Pinus"). Three plots of size $20 \mathrm{~m} \times 20 \mathrm{~m}$ were established in mixed Pinus-Cinnamomum stands at age of 24 and 45 years old and corresponding pure species stands (Pinus and Cinnamomum) at each age, amounting to 18 plots. The another site is located in Taolin forestry station $\left(28^{\circ} 55^{\prime} \mathrm{N}, 113^{\circ} 03^{\prime} \mathrm{E}\right)$ in Miluo county, approximate $100 \mathrm{~km}$ from the main site with similar climate and parent soil type. The mean annual precipitation is about 1353.6 and mean annual temperature is $16.9{ }^{\circ} \mathrm{C}$. Here, only the smaller patches of mixed and pure species stands with 10 years old Pinus and Cinnamomum were 
found. Therein three plots of $12 \mathrm{~m} \times 12 \mathrm{~m}$ in mixed forests stands and corresponding pure stands were set up as conducted above. Thereby our study consisted of 27 plots of mixed Pinus-Cinnamomum plantations and corresponding monocultures at age of 10,24 and 45 years old. All the stems were recorded and selected site characteristics are presented in Table 1. More detailed information about the experimental site and soil condition referred to Wen et al. [26].

\section{Fine root sampling and processing}

The root sampling was carried out in April 2013. Six soil cores in each plot were taken randomly in each square plot by using soil steel auger (diameter of $10 \mathrm{~cm}$ ) to the soil depth of $30 \mathrm{~cm}$ and sliced to three layers $(0-10$, $10-20$, and $20-30 \mathrm{~cm})$. A preliminary survey had shown that very few fine roots occurred below $30 \mathrm{~cm}$ soil depth here. All the samples were labeled and transferred to plastic bag, sealed, and transported to the laboratory in $4{ }^{\circ} \mathrm{C}$ refrigerator.

In the laboratory, the processes of root separation off the soil were conducted with floatation method $[13,17$, 27]. All the roots were collected with sieve of $0.65 \mathrm{~mm}$ aperture. The washed fine roots were poured and suspended in water, then sorted to Pinus and Cinnamomum, live and dead ones visually according to morphological traits, turgescence, root elasticity, colour, periderm surface structure, and exposure degree of steles. As there were quite few other tree and understory species, the other species roots were discarded. Living roots of Pinus and Cinnamomum are intact, tough, and flexible. In contrast, dead roots were brittle and fractured easily and were distinguished by a dark to grey cortex and stele, or the complete loss of the stele and cortex. Live fine-root samples of each species were suspended in a water-filled transparent tray on a scanner (image resolution: $400 \mathrm{dpi}$ ) to facilitate root dispersing. The morphological characteristics of fine roots were analyzed using the root analysis system WinRHIZO 2013 (Regent Instruments Inc., Quebec, Canada) by using images obtained. Thereafter, the root samples were oven-dried at $60{ }^{\circ} \mathrm{C}$ to constant weight. The specific root length (SRL) $\left(\mathrm{m} \mathrm{g}^{-1}\right)$ was determined with the total root length by divided root dry weight.

\section{Data analysis}

All data were tested for a normal distribution with the Shapiro-Wilk test. Analysis of variance (ANOVA) or a non-parametric Mann-Whitney $U$ test was used to detect significant differences among three forest types. Differences between means were evaluated by Tukey's test of honestly significant difference. To examine whether overyielding occurred, the relative yield total (RYT) was calculated as the ratio of expected fine root biomass in the mixture to the expected fine root biomass based on the adjusted fine root biomass per basal area in corresponding monocultures, as suggested by Lei [17] and $\mathrm{Ma}$ [28]. More specifically, the expected fine root biomass in mixture was calculated with formula.

$$
\mathrm{B}_{\text {expected }}=\sum\left(\mathrm{B}_{\mathrm{i}} \times \mathrm{BA}_{\mathrm{i}}\right)
$$

where $B_{i}$ is the observed fine root biomass per basal area of species $i$ in pure stands, and $\mathrm{BA}_{\mathrm{i}}$ is the basal area of species $i$ in the mixture. The contributions of the different species, i.e. Pinus and Cinnamomum, to the relative yield total were calculated as the quotient of the fine-root biomass per basal area of each species at a particular stand

Table 1 Stand characteristics in pure species Pinus stands, pure Cinnamomum stands and mixed Pinus-Cinnamomum stands at the age 10, 24 and 45 years old (mean \pm standard deviation)

\begin{tabular}{|c|c|c|c|c|c|c|}
\hline Stand & Age & Species & $\begin{array}{l}\text { Stand density } \\
\left(\mathrm{n} \mathrm{ha} \mathrm{h}^{-1}\right)\end{array}$ & $\begin{array}{l}\text { Diameter at breast } \\
\text { height }(\mathrm{cm})\end{array}$ & Height (m) & $\begin{array}{l}\text { Basal area } \\
\left(\mathrm{m}^{2} \mathrm{ha}^{-1}\right)\end{array}$ \\
\hline \multirow[t]{3}{*}{ Pinus stands } & 10 & Pinus massoniana & 2592 & $9.38 \pm 3.26$ & $5.28 \pm 3.97$ & 20.06 \\
\hline & 24 & Pinus massoniana & 2050 & $14.18 \pm 4.34$ & $12.86 \pm 6.52$ & 35.37 \\
\hline & 45 & Pinus massoniana & 600 & $21.40 \pm 5.30$ & $12.47 \pm 1.88$ & 22.84 \\
\hline \multirow[t]{3}{*}{ Cinnamomum stands } & 10 & Cinnamomum camphora & 2708 & $7.77 \pm 2.60$ & $5.99 \pm 1.25$ & 14.26 \\
\hline & 24 & Cinnamomum camphora & 900 & $17.02 \pm 6.52$ & $13.71 \pm 2.74$ & 23.46 \\
\hline & 45 & Cinnamomum camphora & 800 & $21.06 \pm 6.73$ & $13.24 \pm 2.29$ & 30.63 \\
\hline \multirow{6}{*}{$\begin{array}{l}\text { Mixed Pinus-Cinnamo- } \\
\text { mum stands }\end{array}$} & 10 & Pinus massoniana & 902 & $7.64 \pm 1.82$ & $4.73 \pm 0.82$ & 4.37 \\
\hline & & Cinnamomum camphora & 1689 & $8.14 \pm 2.81$ & $7.20 \pm 0.73$ & 9.83 \\
\hline & 24 & Pinus massoniana & 267 & $19.88 \pm 5.06$ & $12.35 \pm 1.64$ & 7.80 \\
\hline & & Cinnamomum camphora & 592 & $15.27 \pm 5.92$ & $11.41 \pm 3.13$ & 12.45 \\
\hline & 45 & Pinus massoniana & 250 & $19.69 \pm 4.10$ & $12.37 \pm 2.60$ & 7.91 \\
\hline & & Cinnamomum camphora & 325 & $20.94 \pm 8.54$ & $13.75 \pm 2.79$ & 12.91 \\
\hline
\end{tabular}


age in the mixture to the counterpart value in the monoculture. RYT > 1 indicates overyielding on the stand level or for each component species. Significant differences from 1 were analyzed using $t$ tests or the Mann-Whitney $U$ test according to the data distribution.

To calculate the fine root vertical distribution, we adopted a commonly used equation developed by Gale and Grigal [29]:

$$
\mathrm{Y}=1-\beta^{\mathrm{d}}
$$

Therein, $\mathrm{Y}$ indicates the cumulative proportion of fine root biomass in the soil depth $\mathrm{d}$ (in $\mathrm{cm}$ ). High values of $\beta$ were indicate a large proportion of fine root at deeper soil depths, while low values indicate a large proportion of fine roots near the soil surface. Here we used $\beta$ as criterion to compare fine root vertical distribution of Pinus and Cinnamomum in Pinus-Cinnamomum mixed forests and corresponding monocultures as different ages. All data analyses were conducted with R ( $\mathrm{R}$ 3.0.3, R development Core Team, Vienna, Austria).

\section{Results}

\section{Fine root biomass and overyielding}

The ANOVA results indicated the stand age, soil depth and their interactions exerted significant influence on fine root biomass, while the effects of forest stand were not significant (Tables 2, 3). As the forests grows, the standing fine root biomass decreased with stand ages, averaged as $388.45,269.27$ and $138.59 \mathrm{~g} \mathrm{~m}^{-2}$ in $30 \mathrm{~cm}$ soil depth in 10-, 24- and 45-year-old stands, respectively. The standing fine root biomass was the highest in PinusCinnamomum mixed stands compared to corresponding monocultures at 10- and 24-year stands in $30 \mathrm{~cm}$ depth soil profile (Fig. 1), but significant differences were only detected in 10-year-old forest stands. In mixed stands, Cinnamomum contributed more fine root biomass in the belowground part when compared with the aboveground abundance of mixed tree species. Cinnamomum accounted for the total fine root biomass $81.2,81.3$ and 53.2\% in 10, 24 and 45-year-old Pinus-Cinnamomum
Table 3 The effects of plantation stand, stand age and soil depth on fine root biomass using a three-way analysis of variance

\begin{tabular}{lrrrr}
\hline Factor & df & \multicolumn{1}{c}{ SS } & F value & \multicolumn{1}{c}{ P } \\
\hline Stand & 2 & 2.37 & 2.00 & 0.1361 \\
Age & 2 & 30.68 & 25.91 & $<0.0001$ \\
Depth & 2 & 43.56 & 36.79 & $<0.0001$ \\
Stand $\times$ age & 4 & 7.91 & 3.34 & 0.0105 \\
Stand $\times$ depth & 4 & 1.91 & 0.80 & 0.5228 \\
Age $\times$ depth & 4 & 11.19 & 4.72 & 0.0010 \\
Stand $\times$ age $\times$ depth & 8 & 1.88 & 0.40 & 0.9225 \\
\hline
\end{tabular}

Italic font indicates significant differences at $P<0.05$

mixed stands, respectively. Total fine root necromass showed lower values than fine root biomass and ranged from 17.84 to $96.54 \mathrm{~g} \mathrm{~m}^{-2}$ in the pure Pinus, Cinnamomum and mixed Pinus-Cinnamomum stands at differ ages (Fig. 1). The standing fine root necromass was the highest in the pure Cinnamomum stands at 10- and 45-year stands compared with mixed stands at the corresponding age in $30 \mathrm{~cm}$ depth soil profile, which differed significantly from each stands $(\mathrm{P}<0.05)$ (Table 2$)$. In 24-year-old stands, however, the mixed stands showed the highest fine root necromass.

Relative yield total for each species in mixed plantations were calculated based on fine root biomass per basal area. The results showed RYT of Cinnamomum was bigger than 1 in mixed plantations at all stand ages. Among them, 10- and 24-year-old forest stands showed a relative yield total value for fine root biomass that were significantly different from one $(\mathrm{P}<0.05)$. For Pinus, the RYT showed inconsistent pattern that RYT was higher than one in 10- and 45-year-old mixed stands, while the RYT was marginally lower than one in 24-year-old stand (Fig. 2a). On the stand level, the overall RYT were bigger than one in all the three development stages, but the values of RYT seemed to decline with increasing stand ages, averaged as 1.83, 1.51 and 1.33 in 10-, 24- and 45-yearold stand, respectively (Fig. 2b).

Table 2 The effects of plantation stand and stand age on fine root biomass, fine root necromass and specific root length using a two-way analysis of variance

\begin{tabular}{|c|c|c|c|c|c|c|c|c|c|}
\hline \multirow[t]{2}{*}{ Factor } & \multicolumn{3}{|c|}{ Fine root biomass } & \multicolumn{3}{|c|}{ Fine root necromass } & \multicolumn{3}{|c|}{ Specific root length } \\
\hline & df & F value & $\mathbf{P}$ & df & F value & $\mathbf{P}$ & df & F value & $\mathbf{P}$ \\
\hline Stand & 2 & 1.78 & 0.172 & 2 & 7.99 & $<0.0001$ & 1 & 9.77 & 0.0021 \\
\hline Age & 2 & 23.06 & $<0.0001$ & 2 & 9.90 & $<0.0001$ & 2 & 1.72 & 0.1824 \\
\hline Stand $\times$ age & 4 & 2.97 & 0.0217 & 4 & 1.80 & 0.1318 & 2 & 2.53 & 0.0823 \\
\hline
\end{tabular}

Italic font indicates significant differences at $P<0.05$ 


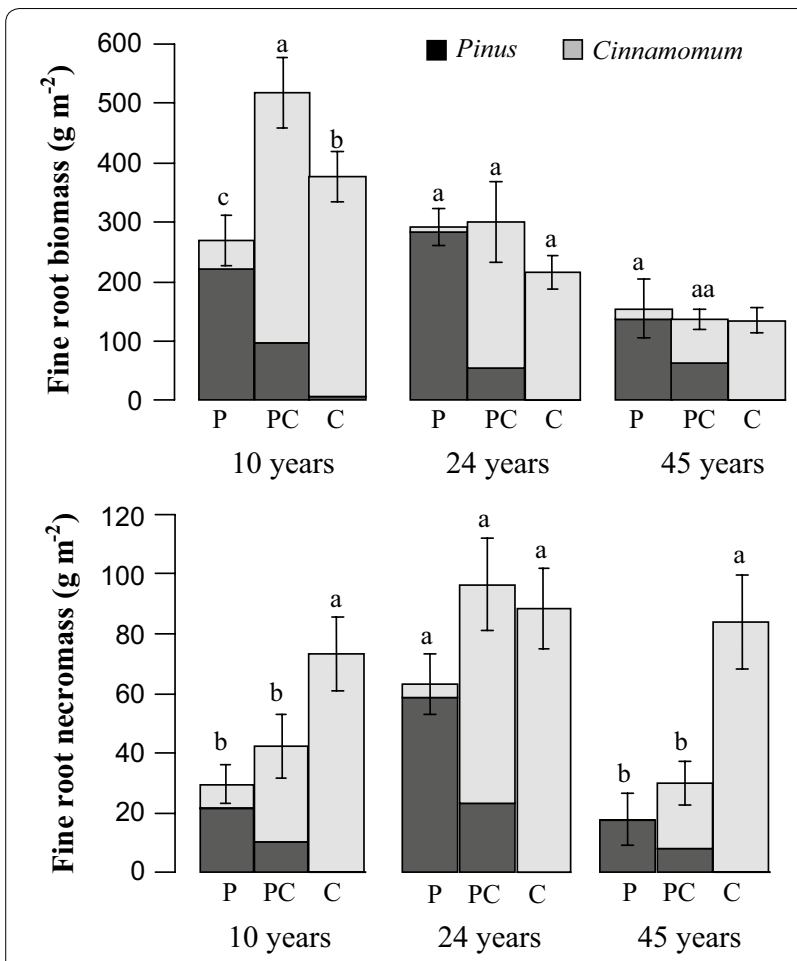

Fig. 1 Live fine root biomass and fine root necromass in pure Pinus stand $(P)$, Cinnamomum stand $(C)$ and mixed Pinus-Cinnamomum stand (PC) in 0-30 cm soil depth at the age of 10,24 and 45 years. Error bars indicate standard errors. Different letters indicate significant differences among different stands within the same ages $(P<0.05)$

\section{Vertical fine root distribution}

The standing fine root biomass decreased gradually with soil depth, and fine root biomass was highest in $0-10 \mathrm{~cm}$ for almost all the cases in the whole stand ages, which accounted for 56.0, 51.7 and $47.2 \%$ in 10-, 24- and 45-year-old stands. When compared with parallel forest stand within the same soil profiles, the fine root biomass was highest in the Pinus-Cinnamomum mixed stands in all the three soil layers in 10-year-old stands and in the top soil layer in 24-year-old stands. But the significant differences were detected only in 10-year-old stands $(\mathrm{P}<0.05)$ (Fig. 3). The abundance of species fine roots declined exponentially with increasing soil depth in the pure and mixed stands. Furthermore, the simulated rooting vertical distribution model of $\beta$ value for Pinus and Cinnamomum growing in pure stands at different stand ages showed the similar patterns that both species allocated more fine roots to the deeper layer with increasing stand ages. Compared the $\beta$ values for Pinus and Cinnamomum in the pure and mixed stands, however, the results showed that the adjusted $\beta$ value for Pinus in pure stands were significantly higher than that in the mixed stands at all forest ages (see Fig. 4). The regression fitting
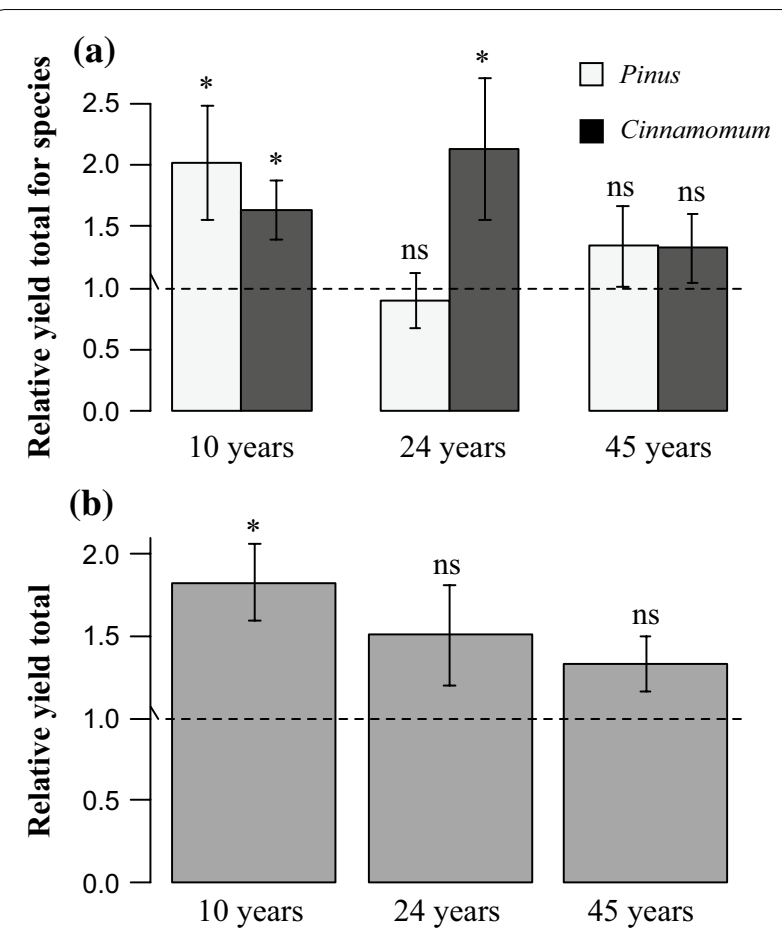

Fig. 2 Relative yield total for each species (a) and relative yield total for total standing fine root biomass (b) and in Pinus-Cinnamomum mixed stands at ages of 10,24, and 45 years old stand age in comparison to monocultures (reference level $=1$ ). Asterisks denote significant differences from 1 with $t$ test or Mann-Whitney $U$ test, $P<0.05$. Each datum shows the mean \pm SE

results showed that the $\beta$ value was $0.915,0.937,0.939$ in pure stands, and $0.911,0.914,0.925$ in mixed stands with quite promising coefficients of determination $\left(\mathrm{r}^{2}>0.95\right.$, $\mathrm{P}<0.01$ ) in forests age of 10-, 24-, and 45-year old, respectively, suggesting fine roots of Pinus were more concentrated in the top soil when mixed with Cinnamomum. For Cinnamomum, the $\beta$ values did not show consistent pattern with increasing stand age as it increased in the pure stands, but decreased in the mixed stands along chronosequence.

\section{Specific root length}

The comparison of specific root length (SRL) in the pure and mixed stands revealed striking differences for Pinus and Cinnamomum. The SRL of Pinus in mixed stands were significantly higher than those of corresponding pure stand, and the differences became more pronounced over time. For Cinnamomum, however, structural trait did not show regular pattern in pure and mixed stand plots. Result from one-way ANOVA revealed that both plantation type and stands age had significant effects on morphology. At in the pure Pinus stand, the SRL changed along the chronosequence, decreasing from $8.84 \mathrm{~m} \mathrm{~g}^{-1}$ in 


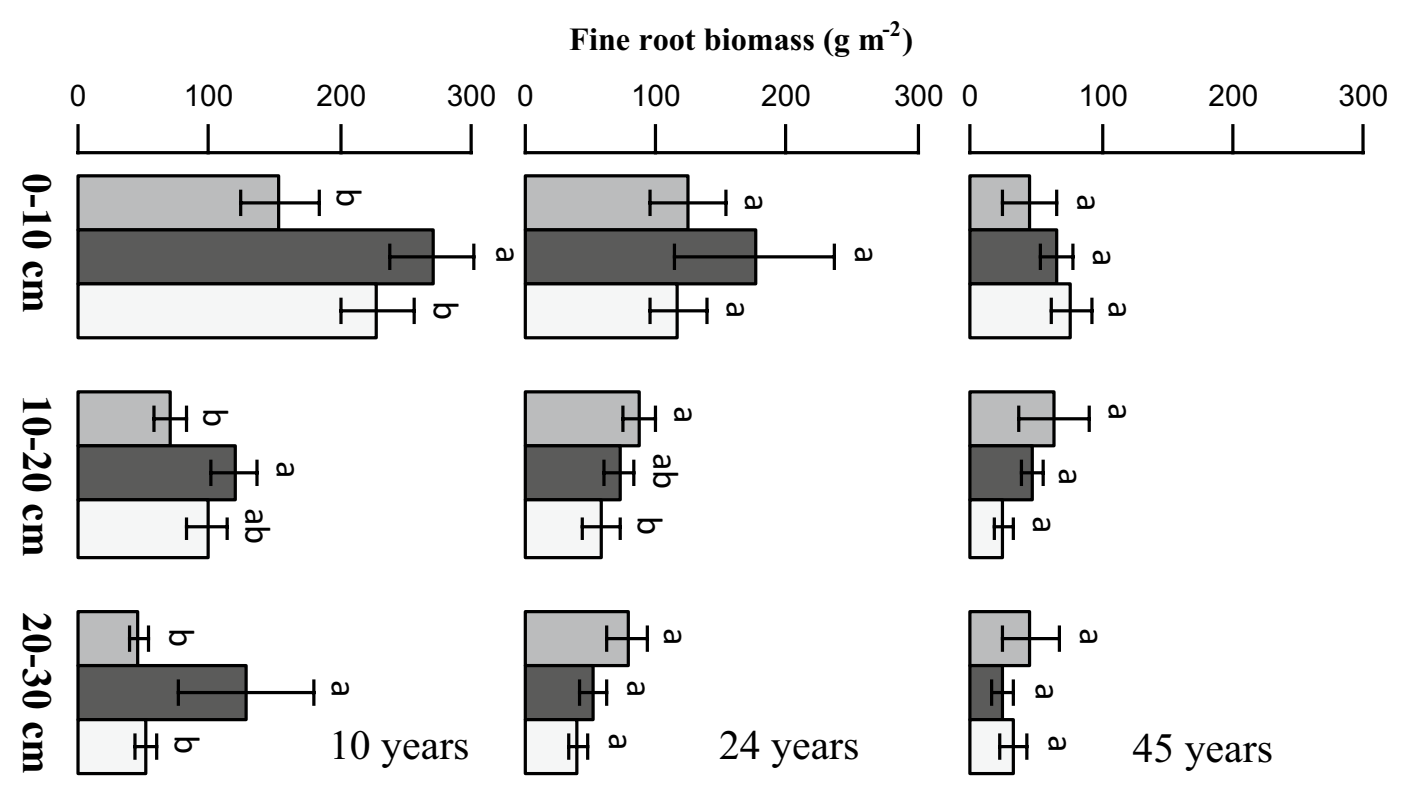

\section{Pinus stands $\square$ Pinus-Cinnamomum stands $\square$ Cinnamomum stands}

Fig. 3 Fine root biomass in pure Pinus, Cinnamomum and mixed Pinus-Cinnamomum stands in 0-10, 10-20 and 20-30 cm soil depth at the age of 10, 24 and 45 years. Error bars indicate standard error. Different letters indicate significant differences among different stands within the same soil profile and age stages $(P<0.05)$

the 10-year old stands to $6.72 \mathrm{~m} \mathrm{~g}^{-1}$ in the 24-year old stands and $6.29 \mathrm{~m} \mathrm{~g}^{-1}$ in the 45 -year old stands. However, the SRL of mixed stands increased along chronosequence. And significant differences were only detected between the 24- and 45-year old stands $(P<0.05)$ (Fig. 5a). For species Cinnamomum, the SRL in the pure stands and mixed stands was basically similar, ranging from 5.24 to $8.90 \mathrm{~m} \mathrm{~g}^{-1}$ (Fig. 5). Comparing with different age stages, the results showed that SRL of Cinnamomum was increased with increase stand age in the pure stands. However, this kind of phenomenon did not show in the Pinus-Cinnamomum mixed stands.

\section{Discussion}

In this study, the fine root biomass seemed to decrease both in pure and mixed stands with increasing stand age, which is likely related to the decreased stand density with development stages here. The high tree density may have accounted for the higher root biomass, which is in agreement with a previous report described for 13-yearold postfire lodgepole pine forests, where the fine root biomass increased with tree density [30]. In contrast to previously published studies that maximum fine root biomass is reached at the canopy closure stage of stand development [2, 31, 32], we found early stand developmental stage with high root biomass. The previous study showed that fine root biomass reached a maximum at an approximate age of 25 years, and then declined to a steady-state, as forests approached maturity. In our study sites, the canopy was already closed, even in the 10-yearold stand due to high planting density. Besides stand ages, the fine root biomass dynamics might also relate to the other stand characteristics, such as tree density, stand structure, basal area and aboveground biomass, etc. [33-35].

When compared with three types of plantations, the fine root biomass was higher in the Pinus-Cinnamomum mixed stands than those in the pure Pinus and Cinnamomum stands in $30 \mathrm{~cm}$ soil depth in 10- and 24-year-old stands. Many previous studies reported the similar pattern that species-rich forests exhibited higher fine root biomass than species-poor stands [12, 36]. Although the absolute fine root biomass in the Pinus-Cinnamomum mixed forests were not significantly higher than that the counterpart monocultures in 24-year-old, and even lower than that in monocultures in 45-year-old stands, the RYT was higher than one, suggesting overyielding when comparing the adjusted fine root biomass per basal area in mixed forest with monocultures (Fig. 2b) [37]. Likewise, fine root overyielding was reported in mixed forests of Eucalyptus grandis and Acacia mangium stands [38], as well as in European beech, sessile oak, Norway spruce and Douglas fir mixed stands at two-, three-, and four-species neighbourhoods in comparison to monocultures [17]. 
Cumulative fine root biomass $(\%)$

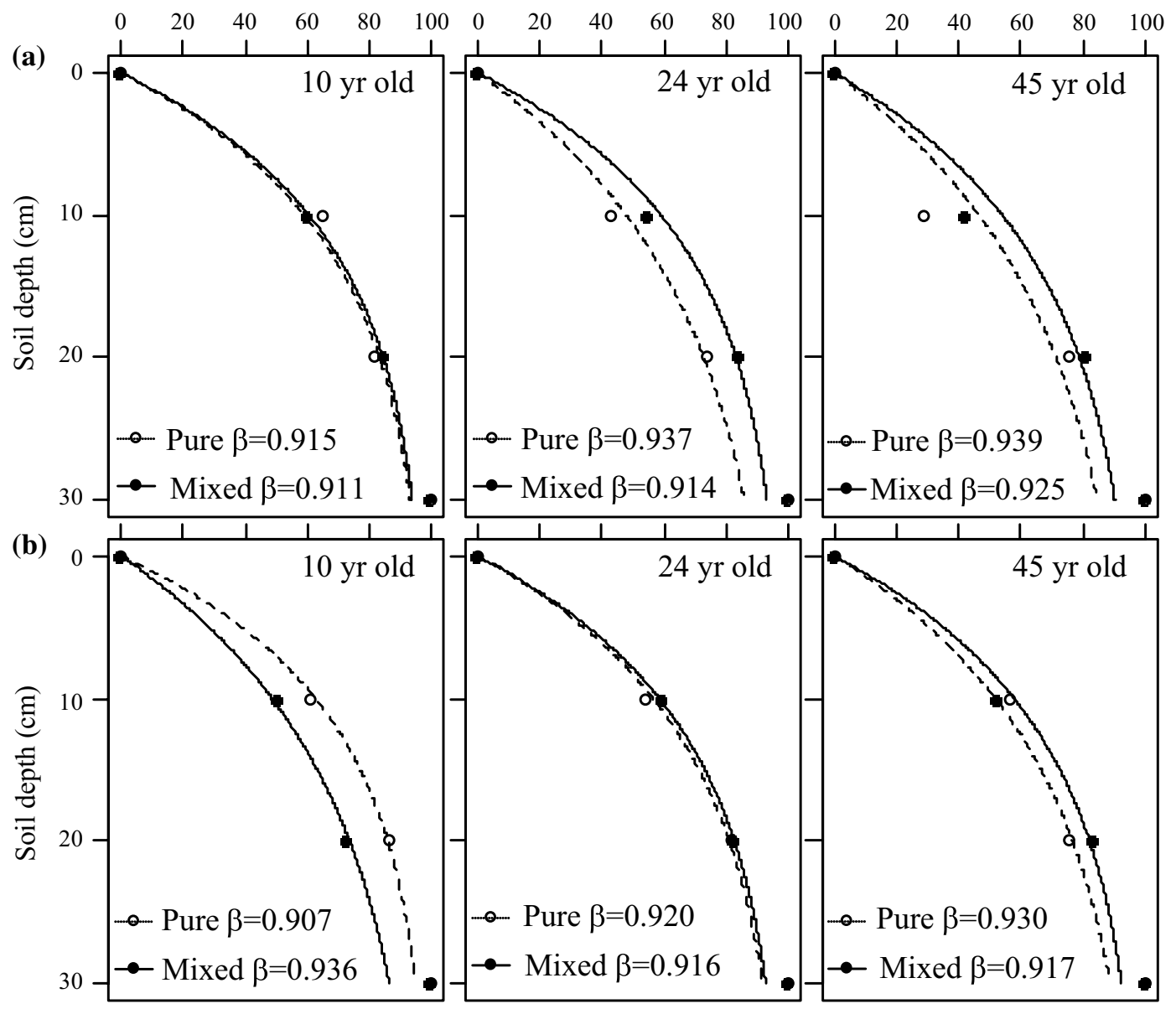

Fig. 4 Cumulative fine root biomass along the soil profiles and the coefficients of the rooting distribution ( $\beta$ ) for Pinus (a) and Cinnamomum (b) in the pure and mixed stands at ages of 10,24 and 45 years. The $\beta$ value indicates the degree of fine root biomass decreases with soil depth

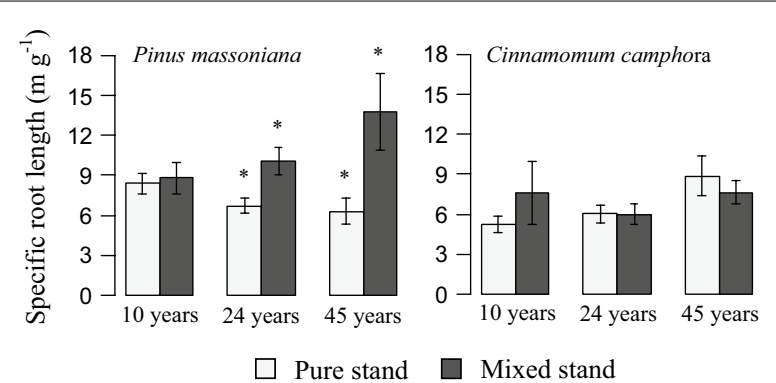

Fig. 5 Comparisons of specific root length for live fine root of Pinus massoniana and Cinnamomum camphora in pure and mixed stands at the age of 10, 24 and 45 years. Error bars indicate standard errors. Asterisks indicate significant differences between pure and mixed stands for the specific species within the same age stages $(P<0.05)$

Here we primarily attempted to assess the variations of these admixing effects over time and expected that the admixing effect would be more pronounced over time, as the interactions between different species are assumed to be more intense over time. On the contrary, in this study, the magnitude of over-yielding in the Pinus-Cinnamomum mixed forests declined with stand development as shown in Figs. 1 and 2. The significant differences between the Pinus-Cinnamomum mixed forests and corresponding monocultures were only detected in 10-yearold forests. Besides, the direct evidence showed that relative yield total decreased from 1.83, and 1.51 to 1.33 in 10-, 24- and 45-year-old stand, respectively. This pattern is consistent the trend that the standing fine root biomass decreased with stand. Therefore, it is likely that the magnitude of fine root overyielding in mixed forests was correlated with fine root biomass and the belowground competitive degree involved instead.

Fine-root turnover contributes substantially to soil organic matter inputs and productivity in forest ecosystems [39]. Thus, understanding the turnover of fineroots is important to unveil the belowground ecosystem 
function. The ratio of live to dead roots (i.e., B/N) could reflect the turnover characteristics of fine roots [36]. In our study, the $\mathrm{B} / \mathrm{N}$ ratio of Pinus was higher than that of Cinnamomum. This could be attributed to a faster decomposition rate or a lower mortality of coniferous species Pinus compared to broadleaved species Cinnamomum [40].

Here we calculated the RYT for the component species in the mixtures to estimate the specific performance and dynamics of each species to the overyielding in the mixtures over time, and foraging strategies as well. In the mixtures, the RYT of late successional species, Cinnamomum, was higher than one for all the stand development stages and the differences were significant from one in 10- and 24-year-old stands. This pattern was supported by data on fine root biomass, which Cinnamomum accounted for $81.2,81.3$ and $53.2 \%$ in 10, 24 and 45 -yearold Pinus-Cinnamomum mixed stands, respectively. Figure 1 suggesting Cinnamomum invested more carbon to belowground fine roots when co-occurring species presents. In contrast, the pioneer species, Pinus, showed significant higher RYT only in 10-year-old stand and then fluctuated from one thereafter.

In our study, we compared the vertical distribution of fine root biomass with the exponential model of Gale and Grigal [29] and found very similar patterns for the overall distribution in pure stands along chronosequence. Two species showed the exponential indicator ( $\beta$ values) increased with stand development. The $\beta$ value indicated that there was clear spatial separation of the fine root systems of the Pinus within $30 \mathrm{~cm}$ soil profile. The Pinus roots occupied the deeper soil layers in the pure stand whereas it shifted to the superficial layers when mixed with Cinnamomum. Many previous researches revealed significant effect of mixed stand on fine root distributions. Bolte and Villanueva [14] suggested that fine root of Picea abies distributed deeper in mixed stands than pure stands. Moreover, in mixed stand of Fagus sylvatica and Quercus Petraea, fine roots of F. sylvatica grew deeper than fine roots of $Q$. petraea [41]. The presence of Cinnamomum in the mixed stands could have pushed the fine root system of Pinus towards the soil surface where the water and nutrient were more enriched. In mixed stand fine roots tend to proliferate and compete with neighbors for nutrients and water by developing a more flexible fine root system when there is more intense belowground competition $[42,43]$. On the other hand, the shallower root allocation could be more susceptible to the drought. For Cinnamomum, the fine root distribution model indicated that there was no obvious spatial separation of the fine root systems within $30 \mathrm{~cm}$ soil profile. Therefore, different tree species may have different strategies for the presence of neighbor species in terms of vertical niche separation.

The specific root length (SRL) was used as indicator for nutrient uptake efficiency and responses to environmental changes or competition [44]. SRL can reflect the root growth strategies on the efficiency of consumption photosynthetic primary product, high SRL indicate high efficiency of using photosynthetic primary product of plant root systems [45]. Our studies showed that SRL of Pinus decreased slightly with increase forest age in monocultures, but increased with stand age in mixtures. In 45-year-old stand, the SRL of Pinus in the Pinus-Cinnamomum mixed stand was up to two-fold higher than that in monocultures, suggesting Pinus exploited water and nutrient resources more efficiently with given carbon investment when growing admixed with Cinnamomum. It is likely that pioneer species, Pinus, was stressed by the competition from the later successional species, Cinnamomum. To what extent the pioneer species can adjust the root morphology to the neighbour species competition could be a big issue. The results were consistent with previous study showing that the specific root length (SRL) and specific root area (SRA) for beech were higher in beech-spruce mixtures than that in monocultures [14]. For Cinnamomum, in contrast, fine root morphology was rather similar in pure and mixed stands. The SRL of Cinnamomum seemed to increase along chronosequence, but no significant differences were detected, in agreement of previous study that mean SRL was not significantly different among the F. sylvatica, Quercus robur and Alnus glutinosa chronosequences [46].

Furthermore, fine-root morphological traits may vary as a consequence of interactions with soil biota, such as ectomycorrhizal fungi, which may confound root plasticity responses to resource availability [47]. This is especially true for pine species which are obligatedly ectomycorrhizal. Unfortunately, we have no ectomycorrhizal data to examine whether this ectomycorrhizal infection effect is mirrored morphological plasticity or otherwise, which merits further investigations.

\section{Conclusions}

Here our experiment detected the variations of admixing effect of fine root biomass with forest development. The results showed fine root overyielding in mixed plantations and this positive admixing effects did not increase over time, instead the magnitude of overyielding in mixed forests was correlated with the degree of belowground interaction and competition degree involved. In 10-year-old stands, two species showed significant admixing positive effects on fine root biomass, while in 24- and 45-year-old stands, the overyielding was mainly 
attributed to the overperformance of late successional species Cinnamomum, which invested more carbon to belowground by increasing the fine root biomass in mixtures, suggesting that the duration time of over-yielding of Cinnamomum roots was probably longer than Pinus. While the pioneer species, Pinus, adapted to the presence of the species Cinnamomum by modification of vertical distribution and root morphological plasticity in the mixtures. The contrast performances of root foraging strategies between early and late successional species by using either extensive adaptation strategy for late successional species Cinnamomum to increase carbon investment into fine root biomass, or intensive adaption strategy for pioneer species Pinus to shift fine root distribution to the top soil layer and to increase SRL in mixtures. These species-specific fine root foraging strategies might imply the differences of forest growth strategies of co-occurring species and likely contribute to the success or failure of particular species during the succession over time.

\section{Authors' contributions}

$\mathrm{PL}$ and WX conceived the idea and designed the experiment. SX, WY and SO performed the experiment and collected the data. WS and PL analysed the data and wrote the manuscript, all authors contributed to the final manuscript. All authors read and approved the final manuscript.

\section{Author details}

${ }_{1}^{1}$ Faculty of Life Science and Technology, Central South University of Forestry and Technology, Changsha 410004, Hunan, China. ${ }^{2}$ National Engineering Laboratory for Applied Technology of Forestry \& Ecology in South China, Central South University of Forestry and Technology, Changsha 410004, Hunan, China.

\section{Acknowledgements}

We acknowledge the assistance of Fang Jiang, Yuqin Xu and Hao Yi in the field and laboratory.

\section{Competing interests}

The authors declare that they have no competing interests.

\section{Availability of data and materials}

The datasets in this study are available from the corresponding author on reasonable request.

\section{Consent for publication \\ Not applicable.}

\section{Ethics approval and consent to participate}

We thank Forest Administration on Hunan and Forest Station of Taolin for the permission to use the site.

\section{Funding}

This study was funded by National Natural Science Foundation of China (31200346 and 31670448).

\section{Publisher's Note}

Springer Nature remains neutral with regard to jurisdictional claims in published maps and institutional affiliations.

Received: 3 July 2017 Accepted: 10 February 2018

Published online: 17 February 2018
References

1. Vogt KA, Vogt DJ, Bloomfield J. Analysis of some direct and indirect methods for estimating root biomass and production of forests at an ecosystem level. Plant Soil. 1998;200:71-89.

2. Claus A, George E. Effect of stand age on fine-root biomass and biomass distribution in three European forest chronosequences. Can J For Res. 2011:35:1617-25

3. Jackson RB, Mooney HA, Schulze ED. A global budget for fine root biomass, surface area, and nutrient contents. Proc Natl Acad Sci. 1997;94:7362-6.

4. McCormack ML, Dickie IA, Eissenstat DM, et al. Redefining fine roots improves understanding of below-ground contributions to terrestrial biosphere processes. New Phytol. 2015;207:505-18.

5. Wells CE, Eissenstat DM. Marked differences in survivorship among apple roots of different diameters. Ecology. 2001;82:882-92.

6. Zeng W, Zhou B, Lei P, et al. A molecular method to identify species of fine roots and to predict the proportion of a species in mixed samples in subtropical forests. Front Plant Sci. 2015:6:313.

7. de Kroon H. How do roots interact? Science. 2007;318:1562-3.

8. Schmid I, Kazda M. Root distribution of Norway spruce in monospecific and mixed stands on different soils. For Ecol Manag. 2002;159:37-47.

9. Reyer C, Lasch P, Mohren GMJ, Sterck FJ. Inter-specific competition in mixed forests of Douglas-fir (Pseudotsuga menziesii) and common beech (Fagus sylvatica) under climate change-a model-based analysis. Ann For Sci. 2010;67:805.

10. Schmid I. The influence of soil type and interspecific competition on the fine root system of Norway spruce and European beech. Basic Appl Ecol. 2002;3:339-46.

11. Meinen C, Leuschner C, Ryan NT, Hertel D. No evidence of spatial root system segregation and elevated fine root biomass in multi-species temperate broad-leaved forests. Trees. 2009;23:941-50.

12. Brassard BW, Chen H, Bergeron Y, Paré D. Differences in fine root productivity between mixed- and single-species stands. Funct Ecol. 2011;25:238-46.

13. Lei P, Scherer-Lorenzen M, Bauhus J. Belowground facilitation and competition in young tree species mixtures. For Ecol Manag. 2012;265:191-200.

14. Bolte A, Villanueva I. Interspecific competition impacts on the morphology and distribution of fine roots in European beech (Fagus sylvatica L.) and Norway spruce (Picea abies (L.) Karst.). Eur J For Res. 2006;125:15-26.

15. Meinen C, Hertel D, Leuschner C. Biomass and morphology of fine roots in temperate broad-leaved forests differing in tree species diversity: is there evidence of below-ground overyielding? Oecologia. 2009;161:99-111.

16. Rewald B, Leuschner C. Belowground competition in a broad-leaved temperate mixed forest: pattern analysis and experiments in a four-species stand. Can J For Res. 2009:128:387-98.

17. Lei P, Scherer-Lorenzen M, Bauhus J. The effect of tree species diversity on fine-root production in a young temperate forest. Oecologia. 2012;169:1105-15.

18. Ma Z, Chen HYH. Effects of species diversity on fine root productivity increase with stand development and associated mechanisms in a boreal forest. J Ecol. 2017. https://doi.org/10.1111/1365-2745.12667.

19. Zhou Z, Shangguan Z. Vertical distribution of fine roots in relation to soil factors in Pinus tabulaeformis Carr. forest of the Loess Plateau of China. Plant Soil. 2007:291:119-29.

20. Schenk HJ. Progress in botany vertical vegetation structure below ground: scaling from root to globe. In: Esser K, Lüttge U, Beyschlag W, Murata J, editors. Progress in Botany, vol. 66. Berlin, Heidelberg: Springer; 2005. p. 341-73.

21. Bouillet JP, Laclau JP, Arnaud M, et al. Changes with age in the spatial distribution of roots of Eucalyptus clone in Congo: impact on water and nutrient uptake. For Ecol Manag. 2002;171:43-57.

22. Bauhus J, Khanna PK, Menden N. Aboveground and belowground interactions in mixed plantations of Eucalyptus globulus and Acacia mearnsii. Can J For Res. 2000;30:1886-94.

23. Makkonen $\mathrm{K}$, Helmisaari HS. Fine root biomass and production in Scots pine stands in relation to stand age. Tree Physiol. 2001;21:S114. 
24. Curt T, Prevosto B. Root biomass and rooting profile of naturally regenerated beech in mid-elevation Scots pine woodlands. Plant Ecol. 2003;167:269-82

25. Bolte A, Rahmann T, Kuhr M, et al. Relationships between tree dimension and coarse root biomass in mixed stands of European beech (Fagus sylvatica L.) and Norway spruce (Picea abies [L.] Karst.). Plant Soil. 2004;264:1-11.

26. Wen L, Lei $P$, Xiang W, et al. Soil microbial biomass carbon and nitrogen in pure and mixed stands of Pinus massoniana and Cinnamomum camphora in stand age. For Ecol Manag. 2014;328:150-8.

27. Böhm W. Methods of studying root systems. Berlin: Springer; 1979. p. 1-3.

28. Ma ZL, Chen Han HYH. Effects of species diversity on fine root productivity increase with stand development and associated mechanisms in a boreal forest. J Ecol. 2017;105:237-45.

29. Gale MR, Grigal DF. Vertical root distributions of northern tree species in relation to successional status. Can J For Res. 1987;17:829-34.

30. Litton CM, Ryan MG, Tinker DB, Knight DH. Belowground and aboveground biomass in young postfire lodgepole pine forests of contrasting tree density. Can J For Res. 2003;33:351-63.

31. Helmisaari HS, Makkonen K, Kellomaki S, et al. Below-and above-ground biomass, production and nitrogen use in scots pine stands in eastern Finland. For Ecol Manag. 2002;165(1):317-26.

32. Børja I, De Wit HA, Steffenrem A, et al. Stand age and fine root biomass, distribution and morphology in a Norway spruce chronosequence in southeast Norway. Tree Physiol. 2008;28(5):773.

33. Finér $L$, Ohashi $M$, Noguchi $K$, et al. Factors causing variation in fine root biomass in forest ecosystems. For Ecol Manag. 2011;261:265-77.

34. Brassard BW, Chen HYH, Bergeron Y, et al. Influence of environmental variability on root dynamics in northern forests. Crit Rev Plant Sci. 2009;28:179-97.

35. Iorio AD, Montagnolii A, Terzaghi M, et al. Effect of tree density on root distribution in Fagus sylvatica stands: a semi-automatic digitising device approach to trench wall method. Trees. 2013:27:1503-13.

36. Liu C, Xiang WH, Tian DL, et al. Overyielding of fine root biomass as increasing plant species richness in subtropical forests in central southern China. Acta Phytoecol Sinica. 2011;35:539-50 (in Chinese with English abstract).
37. Hector A. Overyielding and stable species coexistence. New Phytol. 2006;172:1-3.

38. Laclau JP, Bouillet JP. Mixing eucalyptus and acacia trees leads to fine root over-yielding and vertical segregation between species. Oecologia. 2013;172:903-13.

39. Zeng W, Xiang W, Zhou B, et al. Measurement of belowground diversity of fine roots in subtropical forests based on a quantitative real-time PCR (qPCR) method. Plant Soil. 2017;420(1-2):1-14.

40. Bauhus J, Messier C. Soil exploitation strategies of fine roots in different tree species of the southern boreal forest of eastern Canada. Can J For Res. 1999;29:260-73.

41. Büttner V, Leuschner C. Spatial and temporal patterns of fine root abundance in a mixed oak-beech forest. For Ecol Manag. 1994;70:11-21.

42. Leuschner C, Hertel D, Coners H, Büttner V. Root competition between beech and oak: a hypothesis. Oecologia. 2000;126:276-84.

43. Schenk HJ, Jackson RB. Mapping the global distribution of deep roots in relation to climate and soil characteristics. Geoderma. 2005;126:129-40.

44. Ostonen I, Püttsepp Ü, Biel C, et al. Specific root length as an indicator of environmental change. Plant Biosyst. 2007;141:426-42.

45. Pregitzer KS, Laskowski MJ, Burton AJ, et al. Variation in sugar maple root respiration with root diameter and soil depth. Tree Physiol. 1998;18:665-70.

46. Jagodzinski AM, Ziółkowski J, Warnkowska A, Prais H. Tree age effects on fine root biomass and morphology over chronosequences of Fagus sylvatica, Quercus robur and Alnus glutinosa stands. PLoS ONE. 2016. https:// doi.org/10.1371/journal.pone.0148668.

47. Freschet GT, Swart EM, Cornelissen JHC. Integrated plant phenotypic responses to contrasting above- and below-ground resources: key roles of specific leaf area and root mass fraction. New Phytol. 2015;206(4):1247-60.

\section{Submit your next manuscript to BioMed Central and we will help you at every step:}

- We accept pre-submission inquiries

- Our selector tool helps you to find the most relevant journal

- We provide round the clock customer support

- Convenient online submission

- Thorough peer review

- Inclusion in PubMed and all major indexing services

- Maximum visibility for your research

Submit your manuscript at www.biomedcentral com/submit 